\title{
THE INFLUENCE OF CHANGE IN THE EXPENDITURE OF PUBLIC ORGANIZATIONS ON THE INDICATORS OF DEMOCRACY DEVELOPMENT IN UKRAINE
}

\author{
Iryna Tkachuk \\ PhD, Associate Professor, Banking University, Andriivska Str., 1, Kyiv, Ukraine, 04070. \\ Phone number+380506148996; Email Address Tkachuk.Iryna.IT@gmail.com
}

Received 0804 2020; Accepted 31082020

\begin{abstract}
The development of democracy and the activities of non-governmental organizations are very closely interrelated. However, scientists have only described this relationship verbally, while virtually no evidence has been obtained from mathematical analysis. The purpose of the article is to research the impact of changes in expenditures of NGOs on indicators of democracy development in Ukraine and, based on the results obtained, make suggestions as to the possibility of using expenditures of NGOs to increase the level of democracy in Ukraine. Methods and approaches of economic and mathematical analysis were used in the course of the research. In particular, the method of correlation and regression analysis and scenario approach. The study is based on the official data from the State Statistics Service of Ukraine and materials from the NGO "Freedom House". The study period is 13 years. The results of the study indicate that there are links between the indicators of democracy in Ukraine and the expenditures of NGOs. It has been established that such objects of NGOs' expenditures as "charity expenditures" and "material costs and payments for services" influence the formation of the democracy index in Ukraine and thus, managing these expenditures, it is possible to influence both the general level of democracy in Ukraine and its individual elements.
\end{abstract}

Keywords: civil society, democracy, public organizations, expenditures of public organizations, democracy index.

JEL Codes: L31, G59, C10.

\section{Introduction}

Civil society institutes are called "the schools of democracy". And rightly so, because they really teach the members of society to be active, to take the responsibility to make decisions, and to mobilize other representatives into groups for the satisfaction of collective and individual interests. In this respect, the positive impact of the activities of NGOs on the development of democracy is recognized in all democratic societies. Moreover, such opinions may also be found in Ukraine.

A number of scholars have explored the role of non-governmental organizations in the establishment and development of democracy. For example, R. Flacks, (Flacks, 1996) argued that democracy is not possible without a strong civil society, a prerequisite for which is the existence of a network of strong non-governmental organizations; V. Soloshenko explored the role of German nongovernmental organizations in building democracy in Ukraine (Soloshenko, 2015, p. 60); A. Kuznetsov and L. Ignatenko conducted a thorough analysis of participatory democracy, examining its content and historical peculiarities of formation on the example of political schools of the USA (Kuznetsov and Ihnatenko, 2010); A. Pedahzur (Pedahzur, 2018) emphasizes the triple role of civil society in defending democracy in Israel. A. Androniceanu (Androniceanu, 2015) makes an analysis of good and democratic governance within the central and local administration of Romania. The analysis of the results contributed to the identification of key pillars of good governance.

However, virtually all of the research carried out was based on the use of "logic apparatus" and other non-mathematical methods, while mathematically they are still unexplored.

Copyright (C) 2020. Published by Vytautas Magnus University. This is an open access article distributed under the terms of the Creative Commons Attribution Non-Commercial 4.0 (CC BY-NC 4.0) license, which permits unrestricted use, distribution, and reproduction in any medium provided the original author and source are credited. The material cannot be used for commercial purposes. 
Thus, we consider it important to research the links that emerge between the activities of civil society institutions and the development of democracy in Ukraine through econometric methods, based on which we will be able to model how we could influence the development of democracy itself through the activities of public organizations.

The aim of the presented research is to carry out a study of the impact of changes in the expenditures of non-governmental organizations on the indicators of democracy development in Ukraine and to make proposals on the possibility of using the expenditures of non-governmental organizations to increase the level of democracy in Ukraine based on the results obtained.

The object of the research is the economic relations arising from the management of financial resources of public organizations.

The subject of the research is the influence of changes in the expenditures of NGOs on democracy indicators in Ukraine.

The following methods of economic and mathematical analysis were used in the research: correlation and regression analysis, and the scenario method. It is important for correlation and regression analysis that the phenomena and processes under study have mathematical expression, so to characterize the activity of Ukrainian public organizations we will use their expenditures for the period of 2016-2018 (both aggregate and in the context of such constant items within the period as taxes and compulsory payments; remuneration; social assistance; deductions for social events; material costs and payments for services; charitable activities; and other use of funds (State..., 2020)). The data of the expenditures of NGOs used for the analysis are presented in Appendix A. To characterize the level of democracy development, we use the Nations in Transit Democracy Index, which is calculated annually by the Freedom House International Human Rights Organization (Freedom House. Web site, 2020). The democracy index is composed of elements such as national democratic governance; election process; civil society; independent media; local democratic governance; legal framework and independence; and corruption. The contents of each of the elements of the democracy index are disclosed on the website of "Freedom House" (Freedom House. Nations in Transit. Methodology, 2020)

Each of the elements is rated on a scale of 1 to 7 , where 1 is the best value which denotes the absolute freedom of existence of the element under study, and 7 denotes absolute lack of freedom. The general index of democracy is established by determining the average of its elements and also ranges from 1 to 7 , where 1 means that the state is the most democratic (in all respects) and 7 means the least democratic one. Appendix B contains the data on the democracy index.

The scientific knowledge received in the course of the research of the influence of changes in the expenditures of NGOs on the development of democracy in Ukraine will not only expand the methodology of civil society research but will also provide significant practical benefits: the results of the research will help to guide NGOs policy on the use of financial resources to increase the level of democracy in the state.

\section{Research results and discussion}

To analyze the relationship between the expenditures of Ukrainian public organizations and the democracy index in Ukraine, let us construct a linear model of pairwise regression. We choose the democracy index as the dependent variable $(Y)$ and the expenditures of Ukrainian public organizations as the independent variable $(X)$.

The theoretical model of pairwise linear paired regression describing the correlation of the variable $Y$ to variable $X$ is formalized as follows:

$$
Y=\alpha+\beta X+\varepsilon
$$


where $\alpha, \beta$ are the unknown theoretical parameters of regression and $\varepsilon$ is a random theoretical deviation (Babeshko, 2006).

Using the least squares method, the theoretical regression parameters were estimated and a selective equation of the linear regression of the dependence of the democracy index of Ukraine on the expenditures of Ukrainian public organizations was constructed:

$$
Y=2,98+0,001 X
$$

Fig. 1 shows the main results of the correlation and regression analysis of the dependence of the democracy index of Ukraine on the expenditures of Ukrainian public organizations.

\begin{tabular}{|c|c|c|c|c|c|c|c|c|}
\hline SUMMARY OUTPUT & & & & & & & & \\
\hline \multicolumn{9}{|c|}{ Regression Statistics } \\
\hline Multiple R & 0,791699819 & & & & & & & \\
\hline R Square & 0,626788603 & & & & & & & \\
\hline Adjusted R Square & 0,592860295 & & & & & & & \\
\hline Standard Error & 0,157158407 & & & & & & & \\
\hline Observations & 13 & & & & & & & \\
\hline \multicolumn{9}{|l|}{ ANOVA } \\
\hline & $d f$ & SS & MS & $F$ & gnificance $F$ & & & \\
\hline Regression & 1 & 0,456283 & 0,456283 & 18,47391 & 0,00126 & & & \\
\hline Residual & 11 & 0,271686 & 0,024699 & & & & & \\
\hline \multirow[t]{2}{*}{ Total } & 12 & 0,727969 & & & & & & \\
\hline & Coefficients & andard Err & t Stat & P-value & Lower $95 \% \mathrm{U}$ & Upper $95 \%$ & ower $95,0 \% p$ & pper 95,09 \\
\hline Intercept & 2,980066804 & 0,372117 & 8,008422 & $6,47 \mathrm{E}-06$ & 2,161044 & 3,79909 & 2,161044 & 3,79909 \\
\hline X Variable 1 & 0,00104762 & 0,000244 & 4,298129 & 0,00126 & 0,000511 & 0,001584 & 0,000511 & 0,001584 \\
\hline
\end{tabular}

Fig. 1. The results of the correlation and regression analysis of the dependence of the democracy index of Ukraine on the expenditures of Ukrainian public organizations *

* Obtained using Excel tools

Fig. 1 presents estimates of linear regression parameters $\bar{g}(x)=a+b x$, determination coefficient $R^{2}=0,627$ and statistics $F^{*}=18,47$ to test the overall quality of the regression equation. The constructed regression equation is significant at the level of $\theta=0,05$ because $F^{*}>F_{\theta ; l_{1} ; l_{2}}$ ", where $F^{*}$ is the observed value of criterion $F$, and $F_{\theta ; l_{1} ; l_{2}}$ is the critical value found in the $F$ distribution table ( $l_{1}=m$ and $l_{2}=n-m-1$ are the degrees of freedom). According to the results of the research $F^{*}=18,47$, and $F_{\theta ; l_{1} ; l_{2}}=F_{0,05 ; 1 ; 12}=4,844$, which is an indication that the constructed regression equation is significant. If $p<0.00126$, then the regression equation is significant overall at the significance level of $\theta=0,05$.

The analysis of the pairwise correlation coefficients between the expenditures of Ukrainian public organizations and the components of democracy level allows us to determine the closeness 
and direction of the correlation between the expenditures and the elements that make up the Ukrainian democracy index (table 2).

Table 2. Correlation matrix between expenditures and components of the democracy index*

\begin{tabular}{|c|c|c|c|c|c|c|c|c|}
\hline & 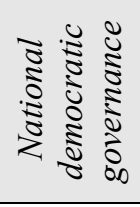 & 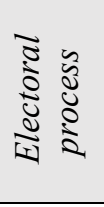 & 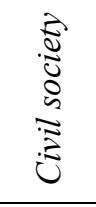 & 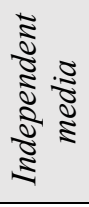 & 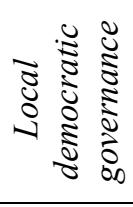 & 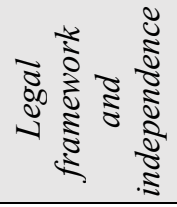 & $\frac{\tilde{0}}{0}$ & 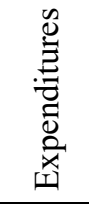 \\
\hline National democratic governance & 1,00 & 0,74 & $-0,58$ & $\mathbf{0 , 8 0}$ & 0,17 & 0,98 & 0,68 & 0,74 \\
\hline Electoral process & 0,74 & 1,00 & $-0,18$ & $\mathbf{0 , 5 8}$ & 0,38 & 0,77 & 0,72 & 0,65 \\
\hline Civil society & $-\mathbf{0 , 5 8}$ & $-0,18$ & 1,00 & $-0,43$ & $-0,13$ & $-0,54$ & $-0,53$ & $-0,06$ \\
\hline Independent media & $\mathbf{0 , 8 0}$ & $\mathbf{0 , 5 8}$ & $-0,43$ & 1,00 & $-0,08$ & 0,74 & 0,63 & 0,65 \\
\hline Local democratic governance & 0,17 & 0,38 & $-0,13$ & $-0,08$ & 1,00 & 0,20 & $\mathbf{0 , 5 7}$ & 0,21 \\
\hline $\begin{array}{l}\text { Legal framework and } \\
\text { independence }\end{array}$ & 0,98 & $\mathbf{0 , 7 7}$ & $-0,54$ & 0,74 & 0,20 & 1,00 & $\mathbf{0 , 6 8}$ & $\mathbf{0 , 7 7}$ \\
\hline Corruption & 0,68 & 0,72 & $-0,53$ & $\mathbf{0 , 6 3}$ & $\mathbf{0 , 5 7}$ & 0,68 & 1,00 & 0,42 \\
\hline Expenditures & 0,74 & 0,65 & $-0,06$ & 0,65 & 0,21 & $\mathbf{0 , 7 7}$ & 0,42 & 1,00 \\
\hline
\end{tabular}

*calculated using Statistica tools

The significant correlation coefficients are shown in bold in Table 2. Thus, we can see that the relationships between the index of expenditures of Ukrainian public organizations and such elements of the democracy index as national democratic governance, the electoral process, the independent media, the legal framework and independence are significant. It should be noted that since the change of the index of democracy from 1 to 7 indicates the deterioration of the situation with democracy, the direct correlation between the expenditures and elements of the democracy index means that the increase of expenditures of Ukrainian public organizations is accompanied by the deterioration of democracy in the country considering certain elements.

Such correlation can be explained by the fact that Ukrainian public organizations are actively responding to the worsening situation in the country, namely to the deterioration of the situation concerning democratic governance, the electoral process, the independent media, the legal framework and independence, and expand their activities to overcome this, thus increasing the expenditures.

However, one can also trace the close relationship between the resulting variables (elements of the democracy index) in the correlation matrix (Table 2), namely between such pairs of indicators as national democratic governance and electoral process, national democratic governance and independent media, national democratic governance and legal framework and independence, electoral process and independent media, electoral process and legal framework and independence, independent media and legal framework and independence, independent media and corruption, local democratic governance and corruption, the legal framework and independence and corruption. The methodology for constructing econometric models also involves verifying the correlation between the factor variables. The relationship between these factors result in multicollinearity, which leads to incorrect conclusions.

It should be noted that this takes into account that the relationship of each pair of variables is influenced by the relationships with other variables. The high value of the pairwise correlation coefficients in the case of multiple regression will not necessarily reflect the high degree of linear relationship between the two variables. 
Therefore, in the case of multiple correlation, the partial correlation coefficients between the components of the level of democracy and the expenditures should also be analyzed (table 3 ).

Table 3. The partial correlation coefficients between the expenditures and the components of the level of democracy

\begin{tabular}{|c|c|}
\hline The component of the level of democracy index & The value of the partial correlation coefficient \\
\hline National democratic governance & $-0,4898$ \\
\hline Electoral process & $-0,1774$ \\
\hline Civil society & $\mathbf{0 , 5 6 0 5}$ \\
\hline Independent media & $\mathbf{0 , 7 5 4 2}$ \\
\hline Local democratic governance & $\mathbf{0 , 7 5 4 4}$ \\
\hline Legal framework and independence & $\mathbf{0 , 7 2 7 9}$ \\
\hline Corruption & $\mathbf{- 0 , 6 6 6 6}$ \\
\hline
\end{tabular}

*calculated using Statistica tools

Partial correlation coefficients show a different situation. According to the results shown in table 3, the expenditures of Ukrainian public organizations have close direct relationship with such components of the democracy index as civil society, independent media, local democratic governance, legal framework and independence. This relationship indicates that the growth of expenditures of Ukrainian public organizations has an inverse effect on the development of democracy in the country. There is a close relationship between the expenditures and the "corruption" element of the democracy index, which indicates that the expenditures of the Ukrainian public organizations lead to a reduction in corruption. Such a relationship is quite logical, since the CSIs, while performing such functions of the CS as opposition and defense, significantly affect the transparency of the activities of all branches of government at all levels.

After analyzing the closeness and direct relationship between the expenditures and components of the democracy index, we construct linear models of pairwise regression between the elements of the democracy index in Ukraine and the expenditures of Ukrainian public organizations (table 4).

Table 4. The research of pairwise relationship between the components of democracy index and expenditures *

\begin{tabular}{|c|c|c|c|c|c|}
\hline Dependent variable & Independent variable & $\mathbf{A}$ & $\mathbf{b}$ & $\boldsymbol{R}^{2}$ & $F^{*}$ \\
\hline National democratic governance & Expenditures & 2,2215 & 0,0021 & 0,55 & 13,56 \\
\hline Electoral process & Expenditures & 1,8824 & 0,0011 & 0,42 & 7,99 \\
\hline Civil society & Expenditures & 2,7265 & $-0,0001$ & 0,00 & 0,04 \\
\hline Independent media & Expenditures & 2,4822 & 0,0009 & 0,42 & 7,91 \\
\hline Local democratic governance & Expenditures & 4,9045 & 0,0003 & 0,04 & 0,51 \\
\hline $\begin{array}{c}\text { Legal framework and } \\
\text { independence }\end{array}$ & Expenditures & 1,3932 & 0,0027 & 0,60 & 16,27 \\
\hline Corruption & Expenditures & 5,3035 & 0,0004 & 0,17 & 2,33 \\
\hline
\end{tabular}

* compiled based on calculations carried out using Excel tools.

Whereas $F^{*}>F_{\theta ; l_{1} ; l_{2}}$ only for the sake of correlation between expenditures and such elements of the democracy index as "National democratic governance"; "Election process"; 
Independent media, and "Legal framework and independence", then at the level of $\theta=0.05$ these regression equations will be significant $\left(F_{\theta ; l_{1} ; l_{2}}=F_{0,05 ; 1 ; 12}=4,844\right)$.

Let us also examine the closeness and direction of the relationship between the components of expenditures and the democracy index separately.

The analysis of the pairwise correlation coefficients between the components of expenditures and the democracy index is shown in table 5.

Table 5. Correlation matrix between the elements of expenditures and democracy index

\begin{tabular}{|c|c|c|c|c|c|c|}
\hline & $\begin{array}{c}\text { Level of } \\
\text { democracy } \\
\text { (general) }\end{array}$ & $\begin{array}{c}\text { Taxes and } \\
\text { compulsor } \\
\text { y payments }\end{array}$ & Remuneration & $\begin{array}{c}\text { Social } \\
\text { assistance; } \\
\text { deductions for } \\
\text { social events }\end{array}$ & $\begin{array}{c}\text { Material costs } \\
\text { and payments for } \\
\text { services }\end{array}$ & Charity \\
\hline $\begin{array}{c}\text { Level of } \\
\text { democracy } \\
\text { (general) }\end{array}$ & 1,0000 & $-0,0476$ & 0,2566 & 0,3911 & $\mathbf{- 0 , 5 7 2 5}$ & $\mathbf{0 , 7 5 0 4}$ \\
\hline $\begin{array}{c}\text { Taxes and } \\
\text { compulsory } \\
\text { payments }\end{array}$ & $-0,0476$ & 1,0000 & $\mathbf{0 , 8 2 3 4}$ & $-0,5018$ & 0,4377 & $-0,5470$ \\
\hline $\begin{array}{c}\text { Remuneration } \\
\text { Social assistance; } \\
\text { deductions for } \\
\text { social events }\end{array}$ & 0,2566 & $\mathbf{0 , 8 2 3 4}$ & 1,0000 & $-0,1286$ & 0,4313 & $-0,2828$ \\
\hline $\begin{array}{c}\text { Material costs } \\
\text { and payments for }\end{array}$ & $\mathbf{- 0 , 5 7 2 5}$ & $-0,4371$ & $-0,1286$ & 1,0000 & 0,0330 & $\mathbf{0 , 5 9 1 1}$ \\
\hline services & $\mathbf{0 , 5 0 1 8}$ & 0,4313 & 0,0330 & 1,0000 & $\mathbf{- 0 , 6 6 2 9}$ \\
\hline Charity & $\mathbf{0 , 7 5 0 4}$ & $-0,5470$ & $-0,2828$ & $\mathbf{0 , 5 9 1 1}$ & $\mathbf{- 0 , 6 6 2 9}$ & 1,0000 \\
\hline
\end{tabular}

*calculated using Statistica tools

Significant correlation indicators are shown in bold in table 5.

The relationship between the general level of democracy and such elements of the expenditures of Ukrainian public organizations as "Material costs and payments for services" and "Charity" is close. Furthermore, there is a close inverse relationship between the general level of democracy in Ukraine and material costs and charity, and a close direct relationship between the general level of democracy and charity. There are also close relationships between factor variables, namely between pairs of expenditure items such as taxes and compulsory payments and remuneration; social assistance, deductions for social events and charity; material costs and payments for services and charity. Relationships between factor variables result in multicollinearity. So, certain situations may lead to incorrect conclusions. Therefore, let us analyze the partial coefficients between the elements of expenditures and the level of democracy (table 6).

Table 6. Partial correlation coefficients between the items of expenditures and the democracy index

\begin{tabular}{|l|c|}
\hline \multicolumn{1}{|c|}{ Item of expenditures } & $\begin{array}{c}\text { The value of the partial } \\
\text { correlation coefficient }\end{array}$ \\
\hline Taxes and compulsory payments & 0,1675 \\
\hline Remuneration & $\mathbf{0 , 6 7 0 3}$ \\
\hline Social assistance; deductions for social events & 0,5100 \\
\hline Material costs and payments for services & $\mathbf{- 0 , 7 4 0 3}$ \\
\hline Charity & 0,4139 \\
\hline
\end{tabular}


Partial correlation coefficients between the expenditures of Ukrainian public organizations and the general democracy index presented in table 6 point to the existence of direct close relationship between the democracy index and such elements of expenditures of Ukrainian public organization as "Remuneration", "Social assistance, deductions for social events" and "Charity", as well as a close inverse relationship between the general democracy index and "Material costs and payments for services". Significant correlation coefficients are typed in bold. However, the partial correlation coefficient between remuneration and the level democracy is 0.6703 , and the pairwise correlation coefficient is -0.2828 . Thus, the model of the dependence of the level of democracy and remuneration showed no relationship.

After analyzing the coefficients of the correlation matrix and the partial correlation coefficients, let us construct linear models of pairwise regression between the items of expenditures (material costs and charity) and the level of democracy (table 7).

Table 7. The research of pairwise relationship between the items of expenditures and the level of democracy *

\begin{tabular}{|c|c|c|c|c|c|}
\hline Dependent variable & Independent variable & $\boldsymbol{A}$ & $\boldsymbol{b}$ & $\boldsymbol{R}^{2}$ & $\boldsymbol{F}^{*}$ \\
\hline Level of democracy (general) & $\begin{array}{c}\text { Material costs and payments for } \\
\text { services }\end{array}$ & 4,824178 & $-0,00097$ & 0,327771 & 5,363472 \\
\hline Level of democracy (general & Charity & 3,958613 & 0,00169 & 0,563163 & 14,18104 \\
\hline
\end{tabular}

* compiled based on calculations carried out using Excel tools.

Since $F^{*}>F_{\theta ; l_{1} ; l_{2}}$, at the level of $\theta=0.05$ these regression equations will be significant ( $\left.F_{\theta ; l_{1} ; l_{2}}=F_{0,05 ; 1 ; 12}=4,844\right)$.

Based on the results of the correlation and regression analysis of the influence of expenditure elements of Ukrainian public organizations on the democracy index of Ukraine in terms of its components, let us analyze the variants of development and change of the level of democracy of Ukraine, changing the factors that influence its formation the most (in terms of its elements) using the scenario approach. The scenario approach enables the analysis of options for changing the democracy index, changing key factors, and making decisions by reviewing the different outcomes of the change and selecting the most effective (optimal) one.

Let us use the scenario approach to analyze changes in the level of democracy, changing the values of the "Material costs" and "Charity" factors for 2018 (table 8). For analysis, let us use a factor variable step of $10 \%$.

Table 8. The influence of the factors "Material costs and payments for services" and "Charity" on the level of democracy

\begin{tabular}{|l|c|c|c|}
\hline \multicolumn{1}{|c|}{ Level of democracy $(\boldsymbol{Y})$} & $\begin{array}{c}\text { Current value of } \\
\boldsymbol{Y}^{* * * *}\end{array}$ & $\begin{array}{c}\text { The value of } \boldsymbol{Y} \text { as } \boldsymbol{X} \\
\text { increases }\end{array}$ & $\begin{array}{c}\text { Increase / Decrease } \\
\text { of } \boldsymbol{Y} \text { (in \%) }\end{array}$ \\
\hline $\begin{array}{l}\text { When changing material costs and payments for } \\
\text { services }\end{array}$ & 4,766726 & 4,76098 & $-0,12 \%$ \\
\hline When changing charity expenditures & 4,058448 & 4,068431 & $0,25 \%$ \\
\hline
\end{tabular}

* where X stands for Material costs or charity

** compiled based on calculations carried out using Excel tools.

*** the theoretical value of $Y$ found by the constructed regression equation 
As Table 8 shows, changing the value of such factors as "Material costs and payments for services" and "Charity expenditures" can directly influence the level of democracy in a country. Accordingly, by increasing "Material costs and payments for services" by $10 \%$, a slight increase in the level of democracy in the country can be achieved (by $0.12 \%$ ). Remember that the level of democracy in the country increases while the democracy index decreases. Thus, the inverse relationship between the democracy index and the material costs and payments for services of public organizations indicates a direct relationship between the expenditures of public organizations by the item and the level of democracy (which is estimated by the democracy index).

With a $10 \%$ change in charity expenditures, the democracy index changes by $0.25 \%$. At the same time, given the direct linear relationship between the variables, an increase in charity expenditures will lead to an increase in the democracy index and, consequently, a decrease in the level of democracy in Ukraine.

Considering the above-mentioned scenarios that accompany the "management" of factor variables to model the level of democracy in the country, let us examine which of the components of the level of democracy are most affected by changes in material costs and payments for services.

Table 9. Correlation coefficients of between material costs and components of the level of democracy *

\begin{tabular}{|c|c|c|c|c|c|c|c|}
\hline & 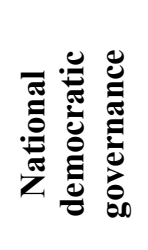 & 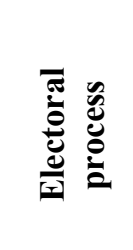 & 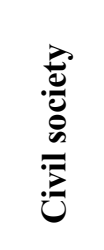 & 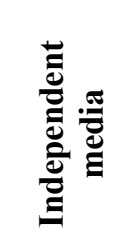 & 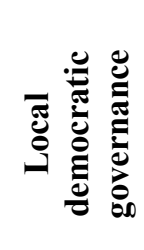 & 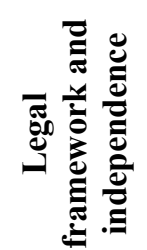 & نั \\
\hline Material costs & $-0,6136$ & $-0,3945$ & 0,615 & $-0,6787$ & 0,2582 & $-0,5456$ & $-0,416$ \\
\hline
\end{tabular}

* compiled based on calculations carried out using Excel tools.

The correlation matrix (table 9) shows that there is a close inverse relationship between material costs and such components of the democracy index as "National democratic governance", "Independent media" and a close direct relationship between material costs and the "Civil society" element. At the same time, such relationships are indicative of the positive influence of increasing material costs on the development of democratic governance and the independence of the media (taking into consideration the improvement of the situation when changing democracy index and its constituents from 7 to 1). Meanwhile, material costs do not have a positive influence on the development of the "Civil society" element itself. Having considered all of the above, let us construct a regression equation for these pairs of variables (table 10).

Table 10. The research of pairwise relationship between the items of expenditures and the components of the level of democracy*

\begin{tabular}{|c|c|c|c|c|c|}
\hline Dependent variable & Independent variable & $\boldsymbol{a}$ & $\boldsymbol{b}$ & $\boldsymbol{R}^{2}$ & $\boldsymbol{F}^{*}$ \\
\hline National democratic governance & $\begin{array}{c}\text { Material costs and payments for } \\
\text { services }\end{array}$ & 5,8953 & $-0,0021$ & 0,37651 & 6,6426 \\
\hline Civil society & $\begin{array}{c}\text { Material costs and payments for } \\
\text { services }\end{array}$ & 2,4528 & 0,0008 & 0,3783 & 6,6929 \\
\hline Independent media & $\begin{array}{c}\text { Material costs and payments for } \\
\text { services }\end{array}$ & 4,1368 & $-0,0011$ & 0,4606 & 9,3922 \\
\hline
\end{tabular}

* compiled based on calculations carried out using Excel tools. 


$$
\begin{aligned}
& \quad \text { Since } F^{*}>F_{\theta ; l_{1} ; l_{2}} \text {, at the level of } \theta=0.05 \text { these regression equations will be significant ( } \\
& \left.F_{\theta ; l_{1} ; l_{2}}=F_{0,05 ; 1 ; 12}=4,844\right) .
\end{aligned}
$$

Let us use the scenario approach to analyze changes in the components of the democracy index due to the changes in the value of the "Material costs and payments for services" factor for 2018 (table 11).

Table 11. The influence of the "Material costs and payments for services" factor on the components of the level of democracy

\begin{tabular}{|l|c|c|c|}
\hline \multicolumn{1}{|c|}{ The components of the democracy index $(\boldsymbol{Y})$} & $\begin{array}{c}\text { Current value of } \\
\boldsymbol{Y}^{* * *}\end{array}$ & $\begin{array}{c}\text { The value of } \boldsymbol{Y} \text { as } \boldsymbol{X} \\
\text { increases }\end{array}$ & $\begin{array}{c}\text { Increase / Decrease } \\
\text { of } \boldsymbol{Y}(\text { in \%) }\end{array}$ \\
\hline National democratic governance & 5,77391 & 5,761774 & $-0,21 \%$ \\
\hline Civil society & 2,497705 & 2,502195 & $0,18 \%$ \\
\hline Independent media & 4,069737 & 4,063035 & $-0,16 \%$ \\
\hline
\end{tabular}

* where $X$ stands for material costs

** compiled based on calculations carried out using Excel tools.

Table 11 demonstrates the scenario of changing such components of the democracy index as "National democratic governance", "Civil society" та "Independent media" while increasing the factor variable "Material costs and payments for services". Thus, we see that the increase of material costs of Ukrainian public organizations by $10 \%$ will lead to a decrease of the democracy index elements: "National democratic governance" by $0.21 \%$ and "Independent media" by $0.16 \%$, as well as the increase of the element "Civil society" by $0.18 \%$. Therefore, the increase in material and service costs of the Ukrainian public organizations leads to a certain improvement in the level of national democratic governance and the functioning of the independent media in the country, while at the same time worsening the organizational capacity and functioning environment of the civil society itself. This can be explained by the fact that today the income structure of Ukrainian NGOs consists of a significant share of the charity proceeds from non-residents, and the priority of foreign donors is to promote democracy and independent media. At the same time, significant amounts of resources are directed by such public organizations to provide material and technical bases for their functioning. Accordingly, such expenditures contribute to the development of national democratic governance and independence of media, but at the same time do not affect the operating environment of Ukrainian public organizations and the independence of the functioning of various public organizations. Let us examine the relationship between the charity expenditures of Ukrainian public organizations and the components of democracy index in Ukraine (table 12). The significant relationships between the expenditures on charity variable and the elements of the democracy index are typed in bold in table 12. Accordingly, there is a close direct relationship between "Charity" and such elements of democracy index as "National democratic governance", "Independent media", and "Legal framework and independence", and a close inverse relationship between "Charity" and "Civil society".

\begin{tabular}{|c|c|c|c|c|c|c|c|}
\hline & 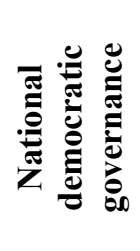 & 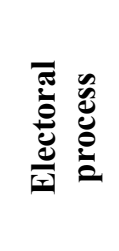 & $\frac{\frac{\pi}{0}}{\frac{\pi}{2}}$ & 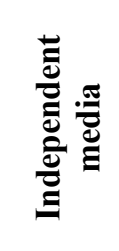 & 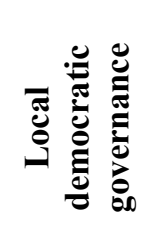 & 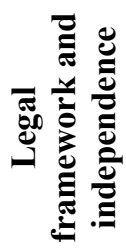 & نَّ \\
\hline Charity & $\mathbf{0 , 8 2 9 7}$ & 0,4112 & $-0,6733$ & 0,7610 & $-0,1299$ & 0,7684 & 0,3927 \\
\hline
\end{tabular}

Table 12. Correlation coefficients between the charity and the democracy index components 
Thus, a change in of expenditures of Ukrainian public organizations on charity will lead to an increase of such elements of democracy index as "National democratic governance", "Independent media", "Legal framework and independence", that is, the movement of values of the democracy index is up the scale from 1 to 7 , respectively means a deterioration of the state on these indicators. On the other hand, the expenditures on charity inversely affects the "Civil society" element. Thus, their growth will improve the conditions of its development and functioning within the state.

Let us construct a regression equation for pairs of variables in table 12 , characterized by significant relationships (13).

Table 13. The research of pairwise relationship between the items of expenditures and the components of democracy index*

\begin{tabular}{|c|c|c|c|c|c|}
\hline Dependent variable & Independent variable & $\boldsymbol{a}$ & $\boldsymbol{b}$ & $\boldsymbol{R}^{2}$ & $\boldsymbol{F}^{*}$ \\
\hline $\begin{array}{c}\text { National democratic } \\
\text { governance }\end{array}$ & Charity & 4,0247 & 0,0037 & 0,6884 & 24,2991 \\
\hline Civil society & Charity & 3,0477 & $-0,0011$ & 0,4533 & 9,1218 \\
\hline Independent media & Charity & 3,2338 & 0,0017 & 0,5791 & 15,135 \\
\hline $\begin{array}{c}\text { Legal framework and } \\
\text { independence }\end{array}$ & Charity & 3,8669 & 0,0042 & 0,5905 & 15,8627 \\
\hline
\end{tabular}

* compiled based on calculations carried out using Excel tools.

Since $F^{*}>F_{\theta ; l_{1} ; l_{2}}$, at the level of $\theta=0.05$ these regression equations will be significant ( $F_{\theta ; l_{1} ; l_{2}}=F_{0,05 ; 1 ; 12}=4,844$ ).

Let us use the scenario approach to analyze changes in the components of the democracy index changing the value of the "Charity" factor for 2018 (table 14).

Table 14. The influence of the "Charity" factor on the components of the democracy index

\begin{tabular}{|l|c|c|c|}
\hline \multicolumn{1}{|c|}{ The components of the democracy index $(\boldsymbol{Y})$} & $\begin{array}{c}\text { Current value of } \\
\boldsymbol{Y}_{* * *}^{* *}\end{array}$ & $\begin{array}{c}\text { The value of } \boldsymbol{Y} \text { as } \boldsymbol{X} \\
\text { increases }\end{array}$ & $\begin{array}{c}\text { Increase / Decrease } \\
\text { of } \boldsymbol{Y} \text { (in \%) }\end{array}$ \\
\hline National democratic governance & 5,996568 & 6,193758 & $3,29 \%$ \\
\hline Civil society & 2,45708 & 2,398017 & $-2,40 \%$ \\
\hline Independent media & 4,136814 & 4,227115 & $2,18 \%$ \\
\hline Legal framework and independence & 6,091846 & 6,314318 & $3,65 \%$ \\
\hline
\end{tabular}

* where X stands for Charity

** compiled based on calculations carried out using Excel tools.

Table 14. shows the likely scenarios for developing of such components of the democracy index as "National democratic governance", "Civil society", "Independent media", and "Legal framework and independence". As we can see, the $10 \%$ increase in expenditures of public organizations on charity has a significant negative impact on the situation of such elements of democracy index as "National democratic governance" $(+3.29 \%)$, "Independent media" (2.18\%) and "Legal framework and independence" (3.65\%) and a positive impact on the development of the civil society in Ukraine $(-2.4 \%)$. 


\section{Conclusions}

The research of the influence of change in the expenditures of public organizations on the indicators of democracy development in Ukraine indicated that there are relationships between such items of expenditures of public organizations as "charity" and "material costs and payments for services".

The results of the scenario method make it possible to formulate proposals on the use of expenditures of public organizations of Ukraine in order to increase the level of democracy in the country.

Therefore, an increase of expenditures under "Material costs and costs of services») of Ukrainian public organizations leads to a certain improvement of the level of national democratic governance and the state of functioning of independent media in the country. At the same time, the increase in expenditures under "Charity" has a positive effect on such an element of the democracy index as "Civil society", while at the same time deteriorating such elements as "National democratic governance", "Independent media" and "Legal framework and independence". Thus, by influencing the structure of expenditures of Ukrainian public organizations, the state (as the regulator) and other significant subjects that influence the activities of public organizations (such as international donors) can also influence the development of democracy in Ukraine. That is why now it is high time to develop and implement an effective strategy for the development of civil society in Ukraine, taking into account the significance of the influence of its organizations on the level of democracy in the state.

\section{References}

Androniceanu, A. (2015). Good democratic governance based on a new model. Revista"Administratie si Management Public “(RAMP). № 24. Pp. 44-55.

Babeshko L. (2006). Basics of Econometric Modeling: course book. - Moscow: ComBook. 432 p.

Flacks, R. (1996). On the Uses of Participatory Democracy. Dissent. №. 13. Pp. 701-708.

Freedom House. Nations in Transit. Methodology - https://freedomhouse.org/report/nations-transitmethodology.

Freedom House. Nations in transit. Ukraine - https://freedomhouse.org/report/nationstransit/2018/ukraine

Freedom House. Web site. https://freedomhouse.org/ [2020 04 04].

Kuznetsov, A., Ihnatenko, L. (2010). Partysypatyvna demokratiia: istorychni narysy [Partisipative democracy: historical essays]. Public administration theory and practice. № 4 (31). Pp. 95-100.

Pedahzur, A. (2018). The role of 'civil society' in the 'defending democracy'. The Israeli response to Jewish extremism and violence. Manchester University Press.

Soloshenko, V. (2015). Rol nimetskykh neuriadovykh orhanizatsii u rozbudovi demokratii v Ukraini [The role of German non-governmental organizations in democracy building in Ukraine]. "Tretia khvylia" demokratyzatsii na terenakh Yevrazii: dosvid novitnoi istorii ta vyklyky suchasnosti. Zbirnyk naukovykh prats.$D U$ "Instytut vsesvitnoi istorii NAN Ukrainy" - The "third wave" of democratization in Eurasia: the experience of modern history and the challenges of the present. Collection of scientific works. -SU "Institute of World History of NAS of Ukraine”. Kyiv: Fenix, Pp. 259-267.

State Statistics Service of Ukraine (2020). Hromadski orhanizatsii v Ukraini. Stat. Biuleten [Public organizations in Ukraine. Statistical Bulletin]. https://ukrstat.org/uk/druk/publicat/Arhiv_u/15/Arch_go_bl.htm [2020 04 04]. 